Mawaizh

Jurnal Dakwah dan Pengembangan Sosial Kemanusiaan

Vol. 8, no. 2 (2017), pp. 259-274.

\title{
Implementasi Nilai-Nilai Dakwah Ekologis dalam Program Pengembangan Kampung Wisata Matras Kelurahan Sinar Baru Kabupaten Bangka
}

\section{Ichsan Habibi}

STAIN Syaikh Abdurrahman Siddik Bangka Belitung, Indonesia ichsan_habibi@gmail.com

\begin{abstract}
Positive contributions and trends in the tourism sector on Bangka Island, especially in the Matras Tourism Village, need to receive appreciation and support from all stakeholders through the management of environmentally friendly and sustainable tourist objects / attractions. To realize this mission, it is necessary to do ecological propaganda (religious values originating from the Qur'an and Hadith) that are in accordance with the sociocultural characteristics of society. This issue is the subject of discussion in this study, especially regarding the values of ecological preaching implemented in the development program of the Mattress Tourism Village. For this reason, a descriptive-qualitative study was conducted by collecting purposive-snowball data from the sample. Furthermore, the collected data was analyzed descriptively-qualitatively so that the values of ecological preaching that had been implemented were identified and the form and process of implementation by the Matras Tourism Village community. The findings show that there are five types of ecological preaching values that have been implemented, namely al-Is (justice), al-Tawazun (balance), al-Intifa 'wa laa al-Fasad (taking benefits without damage), ar-Riayah wa laa al -Israf (nurturing without exaggeration), and al-Tahdits wa alIstikhlaf (renewal). Unfortunately, the value of al-Tahdits wa al-Istikhlaf is still not optimal due to the quality of science and technology. However, the local community has become more aware and intelligent about the importance of ecological preaching values in the development of Mattress Tourism Village. In the future, besides needing to intensify and harmonize the role of ulama and Umara, it must also be carried out to increase the capacity of religious institutions, knowledge and appropriate technology for program implementers, and to involve community participation in planning, implementing and evaluating the Matras Tourism Village development program.
\end{abstract}

Keywords; ecological da'wa values, tourist village, ulama' and umara', participation 


\begin{abstract}
Abstrak
Kontribusi dan tren positif pada sektor pariwisata di Pulau Bangka, khususnya di Kampung Wisata Matras, perlu mendapat apresiasi dan dukungan seluruh stakeholders melalui pengelolaan objek/atraksi wisata yang ramah lingkungan dan berkelanjutan. Untuk mewujudkan misi tersebut, perlu dilakukan dakwah ekologis (nilai-nilai religius yang bersumber dari al-Qur'an dan Hadits) yang sesuai dengan karakteristik sosiokultural masyarakat. Persoalan inilah yang menjadi pembahasan dalam kajian ini, khususnya tentang nilai-nilai dakwah ekologis yang diimplementasikan dalam program pengembangan Kampung Wisata Matras. Untuk itu, dilakukan penelitian deskriptifkualitatif dengan mengumpulkan data dari sampel secara purposive-snowball. Selanjutnya, data yang terkumpul dianalisis secara deskriptif-kualitatif sehingga dapat ditemukenali nilai-nilai dakwah ekologis yang telah diimplementasikan serta bentuk dan proses implementasinya oleh masyarakat Kampung Wisata Matras. Temuan menunjukkan bahwa ada lima jenis nilai dakwah ekologis yang telah diimplementasikan, yakni al-Adalah (keadilan), al-Tawazun (keseimbangan), al-Intifa' wa laa al-Fasad (mengambil manfaat tanpa merusak), ar-Riayah wa laa al-Israf (memelihara tanpa berlebihan), dan al-Tahdits wa al-Istikhlaf (pembaharuan). Sayangnya, nilai al-Tahdits wa al-Istikhlaf masih kurang maksimal dikarenakan kualitas IPTEK. Namun begitu, masyarakat setempat telah semakin sadar dan cerdas akan pentingnya nilai-nilai dakwah ekologis dalam pengembangan Kampung Wisata Matras. Ke depannya, selain perlu lebih mengintensifkan dan menyelaraskan peran ulama' dan umara', juga mesti dilakukan peningkakan kapasitas kelembagaan agama, pengetahuan dan teknologi tepat guna pelaksana program, serta pelibatan partisipasi masyarakat dalam perencanaan, pelaksanaan, dan evaluasi program pengembangan Kampung Wisata Matras.
\end{abstract}

Kata Kunci; nilai-nilai dakwh ekologis, kampung wisata, ulama' dan umara', partisipasi

Received: 09-10-2017; accepted: 14-11-2017; published: 02-12-2017

Citation: Ichsan Habibi, 'Impelementasi Nilai-Nilai Dakwah Ekologis dalam Program Pengembangan Kampung Wisata Desa Matras Kelurahan Sinar Baru Kabupaten Bangka', Mawa'izh, vol. 8, no. 2 (2017), pp. 259-274. 


\section{A. Pendahuluan}

Akhir-akhir ini, sektor pariwisata memberikan kontribusi dan tren positif dalam meningkatkan pendapatan dan promosi daerah. Salah satu daerah yang menunjukkan geliat itu adalah Provinsi Kepulauan Bangka Belitung (Babel). Dengan objek/atraksi wisata yang potensial dengan keunikan tradisional, apabila dikelola secara baik dan tepat, maka diproyeksikan akan menjadi sektor unggulan dan penggerak (leading sector) di bidang sosial, ekonomi, budaya.

Potensi objek/atraksi wisata terbesar adalah bahari dan pantai yang beriringan dengan wisata sejarah, kuliner, dan tradisi-budaya lokal. Besarnya potensi wisata bahari dan pantai ini didukung oleh kondisi geografis sebagai wilayah kepulauan. Tercatat, dari $81.725 \mathrm{~km}^{2}$ luas wilayahnya, sekitar $65.301 \mathrm{~km}^{2}$ $(79,90 \%)$ adalah perairan dengan sejumlah pulau besar dan kecil. ${ }^{1}$ Maka tidak mengherankan apabila setiap tahun terjadi peningkatan kunjungan wisatawan, baik nusantara maupun mancanegara, rata-rata 76.995/tahun. ${ }^{2}$

Khusus di Pulau Bangka, salah satu kawasan yang memiliki objek/atraksi wisata potensial adalah Kampung Wisata Matras, Kelurahan Sinar Baru, Sungailiat, Kabupaten Bangka. Salah satu destinasi wisata unggulan yang diresmikan pada tahun 2010 ini dikembangkan melalui kerja sama Dinas Kebudayaan dan Pariwisata Kabupaten Bangka dengan dinas-dinas terkait, LSM/NGOs, dan stakeholders peduli pariwisata. Akan tetapi, berbagai kegiatan pengembangan yang dilakukan selama ini belum sepenuhnya optimal dan berkelanjutan sehingga belum signifikan meningkatkan pendapatan dan promosi daerah serta kesejahteraan masyarakat setempat.

Selain itu, pengembangan Kampung Wisata Matras ini dinilai belum sepenuhnya environmental oriented sebab masih banyak aktivitas masyarakat setempat yang berpotensi merusak, seperti pertambangan (timah dan batu granit), penggundulan hutan, ataupun penggunaan alat tangkap ikan yang berbahaya. Alasan ekonomi lagi-lagi menjadi penyebab dan seakanmenjadi pembenaran atas degradasi lingkungan yang mengancam keberlanjutan kawasan wisata tersebut.

1 Selain dua pulau besar, Bangka dan Belitung, terdapat 1.105 pulau kecil.

2 Disbudpar Bangka, Masterplan dan DED Kawasan Pantai Matras (Bangka: Disbudpar, 2015). 
Dalam konteks krisis ekologis inilah penting untuk dititikberatkan karena menunjukkan kondisi belum optimalnya peran manusia sebagai khalifah fi al-Ardh yang bertanggung jawab mengelola kekayaan sumber daya alam (antroposentrisme). Yang terjadi, manusia malah menunjukkan perilaku yang menyimpang dari ajaran al-Qur'an dan Hadits. Sebagaimana difirmankan Allah SWT:

"Telah tampak kerusakan di darat dan di laut disebabkan ulah perbuatan tangan manusia, supaya Allah SWT merasakan kepada mereka sebagian dari (akibat) perbuatan mereka, agar mereka kembali (ke jalan yang benar)" (QS. Ar-Ruum: 41). ${ }^{3}$

Di sinilah penting untuk mengkaji nilai-nilai religius dalam upaya menjaga keberlanjutan ekosistem serta hubungan antarelemen lingkungan (nilai-nilai ekologis). ${ }^{4}$ Nilai-nilai inilah yang cenderung diabaikan oleh pihak-pihak terkait (masyarakat, akademisi, birokrasi, ataupun stakeholder lainnya. Padahal, dengan karakteristik sosiokultural masyarakatnya (dominan beragama Islam), semestinya al-Qur'an dan Hadits menjadi landasan dasar untuk bisa mendapatkan titik keseimbangan kebutuhan ekonomi dan ekologi (pelestarian lingkungan hidup), selain hubungan dengan Tuhan (Allah SWT) dan sesama manusia. ${ }^{5}$ Jika dikaji lebih jauh, ada banyak ayat al-Qur'an yang membahas tentang ekologi. ${ }^{6}$

Hal ini sejalan dengan pemikiran Gardner yang mendesak agar para environmentalist (pemerhati dan aktivis lingkungan) untuk bekerja sama dengan

3 Departemen Agama Republik Indonesia, Al-Qur'an dan Terjemahan, p. 154.

${ }^{4}$ Syukri Hamzah, Pendidikan Lingkungan, (Bandung: PT Refika Aditama, 2013), p. 34.

5 Dalam penelusuran asbāb al-nuzūl tidak semua ayat al-Qur'an ada sebab nuzul-nya. Dalam analisis ayat ini tidak ditemukan asbāb al-nuzūl. Syaikh Manna al-Qaththan menulis: "Tetapi hal ini tidak berarti bahwa setiap orang harus mencari sebab turun setiap ayat, karena tidak semua ayat al-Qur'an diturunkan karena timbul suatu peristiwa dan kejadian, atau karena suatu pertanyaan. Tetapi ada di antara ayat al-Qur'an diturunkan sebagai permulaan, tanpa sebab, mengenai aqidah iman, kewajiban Islam dan syari'at Allah dalam kehidupan pribadi dan sosial. Al-Jabar menyebutkan; 'Al-Qur'an diturunkan dalam dua kategori: yang turun tanpa sebab, dan yang turun karena suatu peristiwa atau pertanyaan'." Syaikh Manna Al-Qaththan, Pengantar Studi Ilmu Al-Qur'an (Jakarta: Pustaka Al-Kautsar, 2012), p. 95.

6 Menurut Qadir, sekitar 750 ayat al-Qur'an (sekitar seperdelapan isi al-Qur'an) yang bertujuan mendorong kaum beriman untuk menelaah alam, merenungkan, dan menyelidikinya. Lihat Subair, "Agama dan Etika Lingkungan Hidup". Jurnal Tasamuh, Volume 04/1 Tahun 2015, diakses 09 Desember 2017 pukul 19.45 WIB.

Sejalan dengan hal tersebut, menurut Thabathaba'i, al-Qur'an telah mendorong manusia untuk mempelajari ilmu-ilmu kealaman, metematika, filsafat, dan sastra. Selain itu, al-Qur'an telah menyeru manusia untuk mempelajari ilmu-ilmu tersebut sebagai jalan untuk mengetahui yang al-Haq dan Realitas, serta sebagai cermin untuk mengetahui alam, di samping juga adanya manfaat praktis dari ilmu-ilmu tersebuat bagi kesejehteraan manusia. Lihat Husain Heriyanto, Respons Realisme Islam terhadap Krisis Lingkungan (Jakarta: YOI, 2007), p. 41. 
kaum agamawan yang memiliki pengaruh besar dalam masyarakat untuk menyelamatkan bumi. Menurut Gardner, keterlibatan agama merupakan suatu keharusan ilmiah karena agama memiliki, setidaknya, lima aset dalam upaya perlindungan ekologis, yakni 1) kapasitas membentuk kosmologi yang sejalan dengan visi ekologis, 2) otoritas moral, 3) basis pengikut yang besar, 4) sumberdaya materi yang signifikan, dan 5) kapasitas membangun komunitas. ${ }^{7}$

Bahkan jauh sebelumnya, Nasr telah mengingatkan perlunya menghadirkan (kembali) dimensi spiritualitas ke dalam kehidupan bermasyarakat melalui apa yang ia sebut sebagai resakralisasi alam semesta (resacralizadon of nature). Untuk itu, perlu dibangun kosmologi baru yang berbasis tradisi spiritualitas agama yang sarat makna dan kaya kearifan, sumber visi inspirasi dan motivasi bagi masyarakat untuk mengkonstruksi etika lingkungan hidup berkelanjutan. ${ }^{8}$

Gagasan pendekatan religius ini dapat dilakukan melalui cara dakwah (seruan/ajakan) Islam, baik secara bil Lisan, bil Qalam, bil Haal dan bil Hikmah, dengan sasaran membangun partisipasi masyarakat.

Sehubungan dengan persoalan di atas, tulisan yang berangkat dari kajian deskriptif kualitatif ini mencoba mengungkap perihal nilai-nilai dakwah ekologis yang diimplementasikan dalam pengembangan Kampung Wisata Matras serta bentuk dan proses implementasinya. Penjabaran didasarkan pada hasil analisis wawancara, dokumentasi, dan observasi ${ }^{9}$ melalui proses 1) reduksi data (data reduction), 2) penyajian data (data display), dan 3) penarikan kesimpulan (conclusion). ${ }^{10}$

\section{B. Dakwah dan Ruang Lingkupnya}

Dakwah dapat diartikan sebagai seruan atau ajakan menuju kepada keinsyafan atau usaha mengubah situasi menjadi lebih baik dan sempurna, baik terhadap individu maupun masyarakat. ${ }^{11}$ Namun, dakwah tidak bisa diartikan semata-mata sebagai ajakan dengan kata-kata, melainkan juga dengan perbuatan

${ }^{7}$ Ibid., pp. 51-2.

8 Ibid., p. 55.

${ }^{9}$ Moh. Nazir, Metode, p. 121.

10 Ibid., p. 91.

11 Quraish Shihab, Membumikan al Qur'an (Bandung: Mizan, 1992), p. 194. 
(qawlun wa 'amalun), ${ }^{12}$ dengan cara bijaksana dan jalan yang benar sesuai dengan perintah Tuhan, untuk kemaslahatan dan kebijaksanaan mereka dunia dan akhirat (realitas kehidupan). ${ }^{13}$

Pengertian ini menegaskan bahwa:

1. Dakwah menjadikan Islam sebagai rahmatan lil 'alamin yang harus didakwahkan kepada seluruh manusia agar mencapai kebahagiaan hidup dunia dan akhirat. Dalam prosesnya, melibatkan unsur da'i (subyek), maadah (materi), thoriqoh (metode), wasilah (media), dan mad'u (obyek).

2. Dakwah dapat dipahami dengan proses internalisasi, transformasi, transmisi, dan difusi ajaran Islam dalam kehidupan masyarakat.

3. Dakwah juga mengandung arti panggilan dari Allah SWT. dan Rasulullah saw. untuk umat manusia agar percaya kepada ajaran Islam dan mewujudkannya dalam segala segi kehidupannya. ${ }^{14}$

Landasan dasar dakwah ini telah diberikan Allah SWT dalam firman-Nya:

"Serulah (manusia) kepada jalan Tuhanmu dengan hikmah dan pelajaran yang baik dan bantahlah mereka dengan cara yang baik. Sesungguhnya Tuhanmu Dialah yang lebih mengetahui tentang siapa yang tersesat dari jalan-Nya dan Dialah yang lebih mengetahui orang-orang yang mendapat petunjuk."

Dalam pelaksanaan dakwah, terdapat beberapa metode (cara), yakni:

1. Bi al-Lisan, yakni penyampaian pesan dakwah yang dilakukan melalui metode ceramah atau komunikasi lisan.

2. Bi al-Qalam, yakni kegiatan menyampaikan pesan dakwah melalui tulisan seperti buku, majalah, jurnal,artikel, internet dan lainnya.

3. Bi al-Hal, yakni dengan tindakan nyata yang sesuai ajaran Islam dengan apa yang dibutuhkan si penerima dakwah.

4. Bi al-Hikmah, yakni disampaikan dengan cara yang bijaksana, mengedepankan cara persuasif sehingga orang-orang yang didakwahi tidak merasa dipaksa ataupun tertekan dna berakibat menimbulkan konflik.

\footnotetext{
12 M. Dawan Rahardjo, Intelektual, Intelegensia dan Prilaku Politik Bangsa, Risalah Cendekiawan Muslim (Bandung: Mizan, 1996), p. 159.

13 M. Ali Aziz, Ilmu Dakwah (Jakarta: Prenada Kencana, 2004), p. 5; Lihat juga pandangan M. Abu alFatah al-Bayanuni dalam al Madkhal ila 'ilm al-Dakwah pada Faizah dan Lalu Muchsin Effendi, Psikologi Dakwah (Jakarta: Kencana, 2006), p. 7.

14 Wahidin Saputra, Pengantar Ilmu Dakwah (Jakarta: PT Raja Grafindo Persada, 2012), p. 1.
} 
Dalam konteks dakwah ekologi ${ }^{15}$ yang digunakan dalam kajian ini, memberikan pemahaman kepada kita bahwa betapa pentingnya menjaga dan melestarikan lingkungan atau alam. Dengan pemahaman demikian, diharapkan manusia bisa lebih bijaksana dalam memperlakukan alam. Jika tidak, kerusakan alam akibat eksploitasi tanpa mempertimbangkan hak-hak alam, akan menjadi beban sosial bagi masyarakat. ${ }^{16}$

Dakwah ekologi sendiri bisa dikatakan sebagai dakwah untuk memberikan peringatan kepada manusia akan pentingnya alam dan lingkungan dalam kehidupan. Untuk itu, dibutuhkan pemahaman tentang ilmu lingkungan (ekologi) dan upaya pendidikan lingkungan sehingga dapat meningkatkan kesadaran dan kepedulian manusia terhadap kondisi lingkungan.

Al-Qur'an sendiri banyak berisi tentang ayat-ayat ekologi, yang secara tegas menekankan nilai-nilai dasar yang mesti terkandung dalam dakwah ekologi, yakni: ${ }^{17}$

1. Al-'Adalah (adil), yang dapat diartikan keharusan berbuat secara seimbang, tidak berlaku aniaya terhadap alam dan lingkungan (QS. al An'am : 38).

2. Al-Tawazun (seimbang), yakni harmoni dan stabilitas kehidupan yang memerlukan keseimbangan (al-tawâzun wa al-i'tidâl) dan kelestarian di segala bidang. ${ }^{18}$

15 Istilah ekologi berasal dari bahasa Yunani "oikos" yang berarti rumah atau tempat hidup dan "logos" yang berarti ilmu. Jadi secara harfiah, ekologi berarti pengkajian hubungan organisme-organisme atau kelompok organisme terhadap lingkungannya. Sedangkan secara umum, ekologi diartikan sebagai ilmu yang mempelajari interaksi antara makhluk hidup dengan lingkungannya.

Terkait dengan hal ini, Miller memberikan definisi ekologi sebagai ilmu tentang hubungan timbal-balik antara organisme dan sesamanya serta dengan lingkungan tempat tinggalnya. Lihat Heddy Suwasono, dkk. Pengantar Ekologi (Jakarta: Rajawali, 1986), p. 2.

Sementara menurut Soemarwoto, ekologi adalah lmu tentang hubungan timbal-balik antara makhluk hidup dengan lingkungannya, Ibid., p. 5. Selanjutnya, dalam konteks keilmuan, ekologi menggunakan prinsipprinsip utama yang dianut dalam kajian lingkungan, antara lain : a) saling interaksi (interaction), b) saling ketergantungan (interdependence), c) keanekaragaman (diversity), d) keharmonisan (harmony), dan e) keberlanjutan (sustainability), Ibid., p. 7.

${ }^{16}$ Achmad Cholil, Al-Qur'an dan Lingkungan Hidup (Jakarta: PT Raja Grafindo Persada, 2012), p. 54.

17 Ibid., p. 56-7.

18 Al-tawazun dapat juga diartikan sebagai bentuk Allah SWT menciptakan makhluk apa saja disesuaikan dengan kebutuhan makhluk-Nya. Segala makhluk ciptaan Allah SWT, seperti air, udara, tumbuhtumbuhan, dan bahan tambang, tercipta atas dasar pertimbangan dan ukuran yang sangat akurat dan teliti. Seolah-olah di sini Allah SWT memerlukan penelitian lebih dahulu dengan menggunkan standar Hikmah Ilahiah sebelum mencipta. Lihat Hanafi Ahmad, Al-Tafsir Al-'Ilmi Li Al-Ayat Al-Kauniyah fi Al-Qur'an (Mesir: Dar AMa'rifat, tt.), p. 386. 
3. Al-Intifa' wa laa al-Fasad (mengambil manfaat tanpa merusak), yakni alam dan segala isinya dapat dimanfaatkan oleh manusia tapi tidak boleh mengeksploitasinya hingga menimbulkan kerusakan.

4. Al-Riayah wa laa al-Israf (memelihara tanpa berlebihan), yakni memelihara dan merawat alam dan lingkungan, tidak berlebihan hingga merusak kelestariannya.

5. Al-Tahdits wa al-Istikhlaf, yakni kegiatan pembaharuan terhadap sumberdaya alam yang memungkinkan untuk diperbaharui.

\section{Nilai-nilai Dakwah Ekologis dan Bentuk Implementasinya}

Dalam QS. Al-Jatsiyah ayat 12-13 Allah SWT berfirman:

"Allah-lah yang menundukkan lautan untukmu supaya kapal-kapal dapat berlayar padanya dengan seizin-Nya dan supaya kamu dapat mencari karunia-Nya dan Mudah-mudahan kamu bersyukur. Dan Dia telah menundukkan untukmu apa yang di langit dan apa yang di bumi semuanya, (sebagai rahmat) daripada-Nya. Sungguh pada yang demikian itu benarbenar terdapat tanda-tanda (kekuasaan Allah) bagi kaum yang berfikir. ${ }^{19}$

Ayat di atas, menurut Quraish Shihab, menjelaskan bahwa semua yang ada di langit dan di bumi ditundukkan Allah SWT sebagai sumber kenikmatan bagi manusia. ${ }^{20}$ Harapannya, manusia sebagai khalifah harus dapat memelihara alam dengan kemampuan akalnya.

Pelaksanaan amanat sebagai khalifah ini menunjukkan bahwa keterjalinan timbal-balik manusia dengan alam tidaklah bersifat statis yang harus diterima apa adanya, melainkan bersifat suka-rela. ${ }^{21}$ Untuk itu, alam dan lingkungan harus didekati secara etis dan beradab sehingga tidak merugikan keduanya. Andai sekali saja alam tercemar, maka akan sangat sulit bagi manusia untuk menciptakan kemakmuran dan kesejahteraan. ${ }^{22}$

Relasi keduanya dapat terjalin dengan baik, apabila manusia sadar akan pentingnya menjaga keseimbangan alam sebagai suatu sistem yang utuh. Namun apabila terjadi ketidakseimbangan antara pemakaian dan perawatan terhadap alam, maka akan membawa dampak bagi keberlangsungan hidup umat manusia.

19 Departemen Agama Republik Indonesia, Al-Qur'an, p. 816.

${ }^{20}$ Abu Ja'far Muhammad bin Jarir Ath-Thabari, Tafsir Ath-Thabari Jilid 23, p. 281.

${ }^{21}$ Mujiono Abdillah, Agama Ramah Lingkungan Perspektif al-Qur"an, p. 145.

22 Ahmad Syafi'i Ma'arif, Membumikan Islam, p. 30. 
Sayangnya, menurut William Chang, peran manusia telah bergeser, sebelumnya sebagai bagian dari alam dan kini menjadi penguasa alam (antroposentrisme). Manusia makin menunjukkan sikap arogan, terus mengeksploitasi alam tanpa memerhatikan dampak jangka panjang. Maka tidak mengherankan ketika manusia berubah menjadi musuh bagi alam. ${ }^{23}$

Sebagai masyarakat Melayu yang notabene relijius, keberadaan Kampung Wisata Matras, Sinar Baru, Sungailiat, Bangka menjadi berkah tersendiri karena kontribusinya terhadap aspek sosial-ekonomi dan promosi daerah. Besarnya potensi objek/atraksi wisata di kampung ini terlihat dari suasananya yang eksotis, pantai berpasir putih dan berkombinasi dengan batuan besar. Belum lagi didukung oleh atraksi wisata khas lokal seperti kuliner seafood, pesta adat, kesenian dan musik lokal serta atraksi budaya. Maka, tidaklah heran jika kawasan wisata ini sering ditunjuk menjadi tuan rumah berbagai even nasional dan internasional seperti triathlon, grass track, dan motocross.

Untuk itu, diperlukan pengelolaan yang baik dan dukungan dari berbagai pihak terkait sehingga visi dan misi pengembangan Kampung Wisata Matras dapat dicapai. Salah satu cara yang dinilai mampu mencapai cita-cita tersebut adalah mengimplementasikan nilai-nilai dakwah ekologis dalam setiap tahapan pengelolaan Kampung Wisata Matras.

Sayangnya, masih banyak aktivitas masyarakat yang tidak mengindahkan nilai-nilai tersebut. Aktivitas pertambangan timah di kawasan pesisir atau pantai dan tambang batu granit masih banyak dilakukan sehingga memberi dampak negatif terhadap eksistensi dan keberlanjutan objek/atraksi wisata di kawasan ini, misalnya air pantai yang keruh, pasir pantai berlumpur, rusaknya terumbu karang dan zona tangkapan ikan. Padahal, objek wisata bahari atau pantai di kawasan ini menjadi unggulan dan simbol kawasan yang telah mendunia, seperti Parai Tenggiri Beach and Resort, Pantai Matras, Pantai Batu Bedaun, serta Pantai Tapak Antu dengan nuansa diving and snorkling bawah lautnya.

Jadi, dapat disimpulkan bahwa nilai-nilai dakwah ekologis belum sepenuhnya diimplementasikan oleh masyarakat dalam usaha mengelola

${ }_{23}$ William Chang, Moral Lingkungan Hidup, p. 26. 
objek/atraksi wisata Kampung Wisata Matras. Namun begitu, masyarakat terus berupaya mengimplemetasikan nilai-nilai dakwah ekologis --al-'Adalah, alTawazun, al-Intifa' wa laa al-Fasad, dan al-Riayah wa laa al Israf dalam aktivitas keseharian mereka. Misalnya, tambang timah inkonvensionak (TI apung) yang sebelumnya tidak ramah bagi ekosistem, sudah menjadi lebih berkeadilan bagi ekosistem lautnya. Masyarakat pun lebih bijak dan cermat dalam mengeksploitasi sumberdaya yang ada, lebih memikirkan eksistensi dan keberlanjutan ekosistem dari objek/atraksi wisata yang ada. Bahkan, bersama-sama pemerintah daerah, mereka mulai menyusun ketentuan pelarangan aktivitas pertambangan di laut, sebagai tindak-lanjut penetapan Kawasan Ekonomi Khusus (KEK) pariwisata di Kabupaten Bangka. Sebagaimana dinyatakan oleh Sharly berikut:

“... jika dulu itu waktu timah lagi jaya siapa saja boleh menambang di laut dan dengan cara apa saja boleh. Masalah utama muncul ketika para nelayan mulai susah menangkap ikan karena zona tangkap semakin jauh dan juga wisatawan yang mandi di pantai mengeluh karena airnya kotor dan lumpur. Mereka protes ke pemda karena kalo di Pantai Matras khususnya memang aset pemda berbeda dengan Parai Tenggiri, maka hasilnya terbitlah peraturan daerah tentang penetapan Matras ini sebagai Kampung Wisata tahun 2010 silam hingga sekarang. Dan alhamdulillah dampaknya, masayarakat semakin peka dan dilibatkan dalam mengelola objek/atraksi wisata yang ada. Apalagi setelah timah semakin berkurang, sedangkan sektor lain juga lesu maka banyak juga masyarakat yang jika hari libur dan ramai orang mereka berjualan di pantai Matras ini ..." (Sharly, Kalur Sinar Baru) ${ }^{24}$

Begitupun aktivitas perikanan, dapat dikatakan lebih ramah terhadap ekosistem laut. Nelayan tidak lagi menggunakan alat-alat berbahaya untuk menangkap ikan seperti pukat harimau, putas, atau bom. Hasilnya pun cukup memuaskan, bahkan sekarang telah terdapat TPI (Tempat Pelelangan Ikan) di Pantai Batu Bedaun. Selain itu, kegiatan diving dan snorkling bawah laut serta kuliner seafood pun semakin hidup. Hal ini menunjukkan tren positif terhadap implemetasi nilai dakwah ekologis al-Intifa' wa laa al-Fasad dan al-Riayah wa laa alIsraf. ${ }^{25}$ Sebagaimana dinyatakan oleh Kumar dan Arman berikut:

"... Alhamdulillah kita tidak pernah menggunakan alat-alat yang merusak untuk menangkap ikan. kita biasa menggunakan alat yang ramah lingkungan,

24 Wawancara, 17 November 2017.

25 Observasi Lapangan, 15 November 2017 
ikan-ikan yang kita perolehpun lebih segar dan biasanya tiap pagi kita jual di TPI Batu Bedaun itu ..." (Kumar, Nelayan Matras) ${ }^{26}$

“... Dulu pernah ada yang menangkap ikan pakai pukat harimau dan juga alat berbahaya lainnya, tapi oleh nelayan dikejar dan sampai sekarang, alhamdulillah tidak ada lagi. Nelayan di sini kompak dan saling membantu ..." (Arman, Nelayan Matras) ${ }^{27}$

Di darat pun begitu, aktivitas penebangan hutan dan penambangan batu granit yang bermotif ekonomi dilakukan dengan mengikuti ketentuan yang berlaku. Masyarakat setempat mengambil manfaat dari ketersediaan kayu di hutan yang sebagian besarnya berstatus hutan produksi, dan ikut memantau aktivitas illegal logging, bahkan rutin melakukan penghijauan. Sedangkan penambangan batu granit di hutan, mereka lakukan dengan alat yang sederhana sehingga tidak berdampak kepada perusakan lingkungan yang lebih besar.

Apa yang dilakukan masyarakat tersebut dapat dikatakan sebagai cermin dari bentuk implementasi nilai dakwah ekologis al-'Adalah, al-Intifa' wa laa Fasad dan al-Riayah wa laa al-Israf. Lalu, aktivitas penghijauan hutan bekas ladang dan pertambangan mencerminkan nilai dakwah ekologis al-Tahdits wa al-Istikhlaf, yakni bentuk pembaharuan terhadap sumberdaya yang telah rusak, menggantinya dengan sumberdaya yang baru.

Perilaku bijaksana dalam mengelola alam ini sejalan dengan kehendak Allah SWT menciptakan alam sebagai rizki bagi manusia untuk keberlangsungan hidupnya. Sebagaimana termaktub dalam al-Qur'an:

"Dan pada pergantian malam dan siang dan hujan yang diturunkan Allah dari langit lalu dihidupkan-Nya dengan air hujan itu bumi sesudah matinya; dan pada perkisaran angin terdapat tanda-tanda (kekuasaan Allah) bagi kaum yang berakal". (QS. Al-Jatsiyah: 5) 28

Ayat di atas, menurut ath-Thabari, menjelaskan bahwa Allah menciptakan alam sebagai rizki bagi kehidupan manusia melalui air hujan untuk menumbuhkan tumbuh-tumbuhan, buah-buahan dan lain-lain sebagai sumber makanan manusia. ${ }^{29}$

26 Wawancara, 17 November 2017.

27 Observasi Lapangan, 15 November 2017

28 Departemen Agama Republik Indonesia, Al-Qur'an dan ..., hlm. 815.

${ }^{29}$ Abu Ja'far Muhammad bin Jarir Ath-Thabari, Tafsir Ath-Thabari, p. 273. 
Dengan demikian, manusia mesti mampu memanfaatkannya dengan sebaik-baiknya sebagai rasa syukur ${ }^{30}$ atas nikmat yang telah dianugerahkan Allah SWT. Dengan begitu, nikmat yang diberikan oleh Allah SWT akan bertambah dan terhindar dari ancaman dengan siksa pedih.

Pada dasarnya, beban berat untuk menjaga keberlanjutan ekologis dalam mendukung program pengembangan Kampung Wisata Matras tidak hanya menitikberatkan pada peran individu masyarakat, tetapi juga peran para ulama ${ }^{31}$ dan umara'. Oleh karenanya, ulama', dan juga cendekiawan Muslim, harus berusaha untuk menjadi pionir dan tauladan umat dalam memberikan pemahaman tentang nilai-nilai dakwah ekologis, baik teoretis maupun praktis. Ali Yafie bahkan merekomendasikan konsep fardhu kifayah dalam hukum fikih tentang lingkungan, yakni sebuah kewajiban yang menuntut semua pihak untuk terlibat dalam merealisasikan nilai-nilai religius dalam upaya menjaga lingkungan. ${ }^{32}$

Dalam tataran praktis, konsep fardhu kifayah ini diwujudkan melalui kerja sama semua pihak terkait untuk berbuat mengamankan dan memperbaiki lingkungan, karena sejatinya kerja konservasi lingkungan adalah panggilan syari'at; jika dikerjakan akan mendatangkan manfaat dan pahala, tapi jika dilalaikan berarti melanggar ajaran Allah SWT sehingga akan mendatangkan laknat dan bencana. ${ }^{33}$ Penerapan konsep fardu kifayah ini memerlukan keterlibatan ulama' dan umara' untuk menyampaikan konsep tersebut kepada masyarakat melalui dakwah. Seperti sabda Rasulullah saw. bahwa setiap kamu adalah pemimpin dan setiap pemimpin akan dimintai tanggung jawab atas kepemimpinannya.

${ }^{30}$ Kata syukur dalam bahasa agama mengacu pada pengertian menggunakan atau mengolah nikmat yang dilimpahkan Tuhan sesuai dengan tujuan dianugerahkannya. Pada dasarnya kegiatan apa pun boleh dilakukan, hanya saja manusia diperingatkan bahwa anjuran untuk melakukan hal yang penting dan bermanfaat. Lihat M. Quraish Shihab, Lentera al-Qur'an: Kisah dan Hikmah Kehidupan (Jakarta: Mizan, 2008), p. 107.

Selain itu, konteks syukur juga berkaitan dengan sifat Allah SWT yakni al-Rahman (Maha Pengasih) dan al-Rahim (Maha Penyayang). Dengan adanya kedua sifat Allah SWT ini, diharuskan bagi manusia berusaha menjaga dan memelihara alam sebagai anugerah-Nya, yakni dengan melestarikan tanpa merusaknya dan berusaha hidup berguna bagi diri sendiri dan orang lain, dimana saja dan kapan saja berada. Karena jika keseimbangan ekologis terjadi maka akan berdampak pada keselarasan dan kesejahteraan hidup manusia itu sendiri. Lihat Djohan Effendi, Pesan-Pesan al-Qur'an: Mencoba Mengerti Intisari Kitab Suci, p. 48.

31 Ulama' adalah orang-orang yang memiliki ilmu dan kepahaman tentang ayat-ayat Allah, baik yang bersifat kealamam (kawniyyah) maupun ayat-ayat yang yang tertulis (qur'aniyyah). Oleh karenanya, mereka senantiasa bersikap tunduk, patuh dan selektif kritis dalam menghadapi sesuatu atas dasar takut melanggar kebenaran ayat-ayat Allah SWT. M. Quraish Shihab, Membumikan Al-Qu'an, p. 382.

32 Sukarni, Fikih Lingkungan Hidup (Perspektif Ulama Kalimantan Selatan), (Jakarta: Kementrian Agama RI, 2011), p. 61.

33 Ibid., p. 252. 
Selanjutnya, sebagaimana dikatakan Schumacher, ketika seorang Muslim yang menanam tanaman atau tumbuh-tumbuhan, kemudian buah atau hasilnya dimakan burung atau manusia lainnya maka yang demikian itu adalah shadaqah baginya. Barangsiapa yang menyuburkan tanah bukan milik seseorang, maka ia berhak memanfaatkan tanah itu. Lebih lanjut ia menjelaskan, bahwa hindarilah dua macam kutukan, yaitu membuang kotoran di jalan dan di tempat orang berteduh. Selain itu, janganlah ada yang membuang air kecil pada air yang tergenang, kemudian mandi pula di sana. ${ }^{34}$

Pada akhirnya, dapat dikatakan bahwa membangun relasi yang kuat tentang Allah SWT, manusia, dan alam pada dasarnya adalah usaha untuk membangun lingkungan yang harmonis. Allah SWT adalah tujuan dari relasi itu, sedangkan manusia dan alam adalah dua sisi yang sama. Oleh karenanya, jika semakin kuat keimanan manusia maka akan semakin harmonis pula kondisi alam (ekologi). Akan tetapi sebaliknya, jika semakin kritis dan rusak manusia, maka menandakan makin kritis dan rusak pula kondisi alam. Oleh karena itu, dari kondisi-kondisi relasi yang tidak harmonis sulit diharapkan untuk dapat menghampiri Allah SWT sebagai pencipta alam. ${ }^{35}$

\section{Penutup}

Dari temuan di lapangan, setidaknya lima jenis nilai dakwah ekologis yang telah diimplementasikan oleh masyarakat setempat dalam rangka mendukung program pengembangan Kampung Wisata Matras, yakni al-'Adalah (keadilan), alTawazun (keseimbangan), al-Intifa' wa laa al-Fasad (mengambil manfaat tanpa merusak), al-Riayah wa laa al-Israf (memelihara tanpa berlebihan), dan al-Tahdits wa al-Istikhlaf (pembaharuan). Masyarakat pun semakin sadar akan potensi objek/atraksi wisata yang ada, dan semakin bijak mengelolanya sehingga berdampak positif bagi sektor ekonomi, kesejehateraan, dan kelestarian ekologi. Meski begitu, nilai al-Tahdits wa al-Istikhlaf masih kurang dalam implementasinya dikarenakan kualitas iptek masyarakat masih terbatas terutama terhadap teknologi tepat guna dan terbaru.

34 M. Quraish Shihab, Membumikan Al-Qu'an, p. 297.

35 Ibid., p. 298. 
Dalam proses implementasinya, masih ditemui beberapa kendala seperti masih ada sebagian masyarakat yang merusak dan tidak begitu concern terhadap nilai dari objek/atraksi wisata setempat. Konsekuensinya, jika hal ini terus dibiarkan maka bukan tidak mungkin akan menjadi benalu bahkan pemicu bagi masyarakat lain untuk juga acuh tak acuh terhadap keberlanjutan ekologis di Kampung Wisata Matras.

Sayangnya sejauh ini, kerja sama berbagai pihak masih belum banyak melibatkan ulama'. Padahal ulama' dan umara' termasuk pilar utama dalam pembangunan umat, dan melalui ulama', nilai-nilai dakwah ekologis bisa tersampaikan pada masyarakat lokal yang notabene Melayu-Islam, tidak hanya sebagai pengetahuan. Untuk itulah, ke depannya, perlu dilakukan pendekatan dan pelibatan secara aktif ulama' sebagai tokoh pemimpin umat yang ucapan didengar oleh masyarakat dan tindakannya pun diikuti dengan sungguh-sungguh. 


\section{DAFTAR PUSTAKA}

Al-Qur'an dan Terjemahan.

Abdillah, Mujiono, Agama Ramah Lingkungan Perspektif al-Qur'an,

Ahmad, Hanafi, Al-Tafsir Al-'Ilmi Li Al-Ayat Al-Kauniyah fi Al-Qur'an, Mesir: Dar AMa'rifat, $\mathrm{tt}$.

Al-Qaththan, Syaikh Manna, Pengantar Studi Ilmu Al-Qur'an, Jakarta: Pustaka AlKautsar, 2012.

Ath-Thabari, Abu Ja'far Muhammad bin Jarir, Tafsir Ath-Thabari Jilid 23.

Aziz, M. Ali, Ilmu Dakwah, Jakarta: Prenada Kencana, 2004.

Bungin, Burhan, Penelitian Kualitatif, Jakarta: Kencana Predana, 2011.

Chang, William, Moral Lingkungan Hidup, Yogyakarta: Balai Pustaka, 2009.

Cholil, Achmad, Al-Qur'an dan Lingkungan Hidup, Jakarta : PT Raja Grafindo Persada, 2012.

Disbudpar Bangka, Masterplan dan DED Kawasan Pantai Matras, Bangka: Disbudpar, 2015.

Effendi, Djohan, Pesan-Pesan al-Qur'an (Mencoba Mengerti Intisari Kitab Suci),

Faizah dan Lalu M. Effendi, Psikologi Dakwah, Jakarta: Kencana, 2006.

Hamzah, Syukri, Pendidikan Lingkungan, Bandung: PT Refika Aditama, 2013.

Heriyanto, Husain, Respons Realisme Islam terhadap Krisis Lingkungan, Jakarta: YOI, 2007.

Maiarif, Ahmad Syafi'i, Membumikan Islam.

McIntosh, dkk, Tourism Principles, Practices and Philoshopies, New York: Jhon Wiley and Sons Inc, 1990.

Moelong, Lexy J., Metodologi Penelitian Kualitatif, Bandung: PT. Remaja Rosdakarya, 2011.

Nazir, Moh., Metode Penelitian, Jakarta: Ghalia Indonesia, 2009.

Priasukmana, dkk, Pembangunan Desa Wisata: Pelaksanaan Undang-Undang Otonomi Daerah, Jakarta: LIPI Press, 2001.

Rahardjo, M. Dawan, Intelektual, Intelegensia dan Prilaku Politik Bangsa, Risalah Cendekiawan Muslim, Bandung: Mizan, 1996.

Saputra, Wahidin, Pengantar Ilmu Dakwah, Jakarta: PT. Raja Grafindo Persada, 2012.

Shihab, M. Quraish, Membumikan al-Qur'an, Bandung: Mizan, 1992. Lentera al-Qur'an (Kisah dan Hikmah Kehidupan), Jakarta: Mizan, 2008.

Subair, "Agama dan Etika Lingkungan Hidup”, Jurnal Tasamuh, Volume 04/1 Tahun 2015.

Sugiyono, Metode Penelitian Kuantitatif, Kualitatif dan R\&D, Bandung: Alfabeta, 2011.

Sukarni, Fikih Lingkungan Hidup (Perspektif Ulama Kalimantan Selatan), Jakarta: Kementrian Agama RI, 2011. 
Mawa'izh

Jurnal Dakwah dan Pengembangan Sosial Kemanusiaan

Vol. 8, no. 2 (2017), pp. 259-274.

Suwasono, Heddy, dkk, Pengantar Ekologi, Jakarta: Rajawali, 1986.

Taha, Chabib, Kapita Selekta Pendidikan Islam, Yogyakarta: Pustaka Pelajar, 1996.

Tim Penyusun Kamus Pusat Pembinaan dan Pengembangan Bahasa Depdikbud, Kamus Besar Bahasa Indonesia, Jakarta: Balai Pustaka, 2001.

Yunus, Hadi Sabari, Metodologi Penelitian Wilayah Kontemporer, Yogyakarta: Pustaka Pelajar, 2010. 